\title{
4. A Personal Journey with Anangu History ${ }^{1}$
}

\author{
Bill Edwards
}

\section{Early Life}

Despite an interest in history during school years, my engagement in postgraduate historical research was delayed until retirement. My childhood home was in the town of Lubeck, in the Wimmera district of Victoria, where my paternal grandparents, having migrated from Wales, opened a general store in 1877. My parents later conducted this business until retirement in 1952. In the 1930s, the population of Lubeck, with its store, post office, hotel, school, hall, two churches and railway station, was approximately 75 , with a similar number living on farms in the surrounding area. Living in this small country town, it was beyond imagination that one might progress to university. I left school in 1946 to work in a bank, just as had my three older siblings. A feeling of call to train for the Presbyterian Church ministry led to enrolment in the University of Melbourne in 1950. Appointed to an Aboriginal mission in 1958, I worked for two decades with Anangu Aboriginal people. This experience not only shaped my subsequent life and work on every level, but also prepared me to lecture in Aboriginal Studies in the first Indigenous tertiary education unit in Australia. In this role, I confronted the tendency of some academics to negatively stereotype Aboriginal missions.

As a child in the Wimmera, my knowledge of and contact with Aboriginal people was extremely limited. Before white settlement, this region was occupied by the Jardwadjali people (Clark 1990, p. 256). A century later, these people had been largely forgotten. The only reminders of their earlier presence were grindstones at a sandhill west of Lubeck which had been a campsite, and tree trunks from which bark had been cut to make artefacts. Monuments on nearby roadsides in the 1930s bore inscriptions: 'Major Mitchell passed by here'. These implied that Mitchell's exploratory expedition was the beginning of history in the region, reflecting what W. E. H. Stanner identified as 'the great Australian silence' in Australian history (Stanner 1969, p. 18). I knew that Aboriginal men played for Dimboola in the Wimmera Football League. They were descendants of the Wergaia people who found refuge at Ebenezer Mission, established on the

1 I would like to thank Karen Hughes for her editorial advice and insightful comments on earlier drafts of this chapter. 
banks of the Wimmera River approximately 70 kilometres north-west of Lubeck in 1863. Later, in retirement, I researched the history of Ebenezer as part of a thesis on Moravian Aboriginal Missions in Australia (Edwards 2007). A feature of the Great Depression period of my early years was the movement of swagmen travelling from town to town on goods-trains, camping in railway sheds and obtaining food by doing odd jobs. I recall one of them being Aboriginal, probably descended from Ebenezer residents. In return for food, he gave my father an incised boomerang, now one of my prized possessions. The community service of my parents in this small town and my early observation of their assistance to struggling families in that post-depression period provided a model for my later commitment to support Indigenous people in their struggles.

In that era, few Aboriginal people were household names in mainstream Australia. In the 1930s, David Unaipon from Port McLeay near the mouth of the River Murray in South Australia toured that state and Victoria to speak in churches and other places about his people. In 1945, the Aboriginal Tenor, Harold Blair, sang on the Australian Amateur Hour radio program. In 1949, I attended an Easter Convention in the Wimmera town of Warracknabeal. We camped at the local showgrounds. On a pavilion wall was a photograph of a short stocky Aboriginal man, Doug Nicholls, who won the Warracknabeal Gift footrace in 1929, the year of my birth. As a boy, I collected cards with pictures of Australian Rules footballers. These included Doug Nicholls as a Fitzroy footballer, probably the first Aboriginal player in the Victorian Football League. By the 1940s, the Central Australian landscape painter, Albert Namatjira, was receiving national recognition.

University studies in the 1950s did little to enlarge my knowledge of Aboriginal people. They were ignored in history and other disciplines, and there were probably no Aboriginal students enrolled at the university. My studies in history were confined to Ancient, British, Modern and Church history subjects. However, limited association with Aboriginal people deepened my interest and led eventually to my involvement with them. In 1954, I visited universities around Australia as a staff-worker with a student Christian organisation, the Inter-Varsity Fellowship. A visit to Adelaide in March coincided with the royal tour of Queen Elizabeth and Prince Phillip. Pitjantjatjara people from Ernabella Mission in the north-west of South Australia expressed interest in seeing this couple. They sold dingo scalps for the government bounty to pay for petrol and were driven 1,500 kilometres on the back of a truck, mostly on dirt roads.

This group of young Pitjantjatjara people learned western part singing in the Ernabella School and sang as the Ernabella Choir. I heard them sing in the Adelaide Teachers College and visited them at their accommodation at the Tusmore Presbyterian Church. I could not have imagined that four years later I would be conducting this choir. In 1955, I visited Alice Springs with a work 
party that laid a forecourt for the John Flynn Memorial Church. On the road we met an Ernabella staff member and a Pitjantjatjara man, Andy Tjilari, who were travelling from the Finke railway township to Ernabella. I had met Tjilari in Adelaide with the choir. He was to become a close colleague and lifelong friend as we reciprocally taught each other deeper aspects of our respective cultures. Our relationship reflected a basic Anangu concept, ngapartji ngapartji, 'in turn in turn'.

Two events at university furthered my interest in Aboriginal people. First, students, concerned at the lack of Aboriginal students, raised funds to provide scholarships. This culminated in the establishment of Abschol (Attwood 2003, p. 283). I screened a film on Ernabella, Men of the Mulga, as a fund raiser for Abschol. Secondly, in my final year, I attended a university meeting at which Doug Nicholls, then pastor of an Aboriginal church in Fitzroy, Melbourne, reported on his visit to Western Australia to investigate the effects of the Woomera rocket range on Aboriginal people in the Western Desert region. His report alerted me to ways in which the rights of Aboriginal people were ignored by governments and deepened my interest in the people of this remote region (Clark, 1972). Although this interest was initially motivated by evangelical concerns, contact with students whose concerns were more political broadened my focus as we discussed the burning issues of the 1950s, such as the Korean War and the spread of communist influence in Asia. Doug Nicholls' talk in particular was pivotal to growing my awareness of the dispossession suffered by Aboriginal people and my later involvement interpreting in land rights negotiations. While there was nothing in my university courses to inform me about Aboriginal culture and history, these contacts awakened my interest in Indigenous issues.

During this final year, I heard that there was a vacancy on a north Queensland mission and was invited to meet the Mission Board Secretary during the 1957 Presbyterian Church General Assembly in Melbourne. As an emergency situation had arisen at Ernabella, I was invited to go there. Having had those earlier contacts with Ernabella people and knowing something of the history and policies of the mission through these contacts, I had no hesitation in accepting this offer.

After working at Ernabella for a while, I suspected that the Board appointed me not on the grounds of my tertiary studies but because of my experiences in a country store and in banking. At Ernabella, I was to act as store-keeper and book-keeper among many other tasks. In Melbourne, I was unable to study anthropology to prepare for work in another cultural context, as the universities of Sydney and Western Australia were the only Australian universities offering regular courses in the discipline. Donald Thomson offered a short course in anthropology to honours history students, but when I inquired about auditing 
this course in 1957 it was unavailable because Thomson was embarking on one of his expeditions to the 'Bindabus' (Pintubi) in Central Australia (Batty 2006, p. iv). There were few textbooks on Aboriginal culture available. I went armed with A. P. Elkin's The Australian Aborigines: How to understand them (Elkin 1956) which gave me insights into basic Aboriginal concepts related to the Dreaming and into the intricacies of their kinship systems.

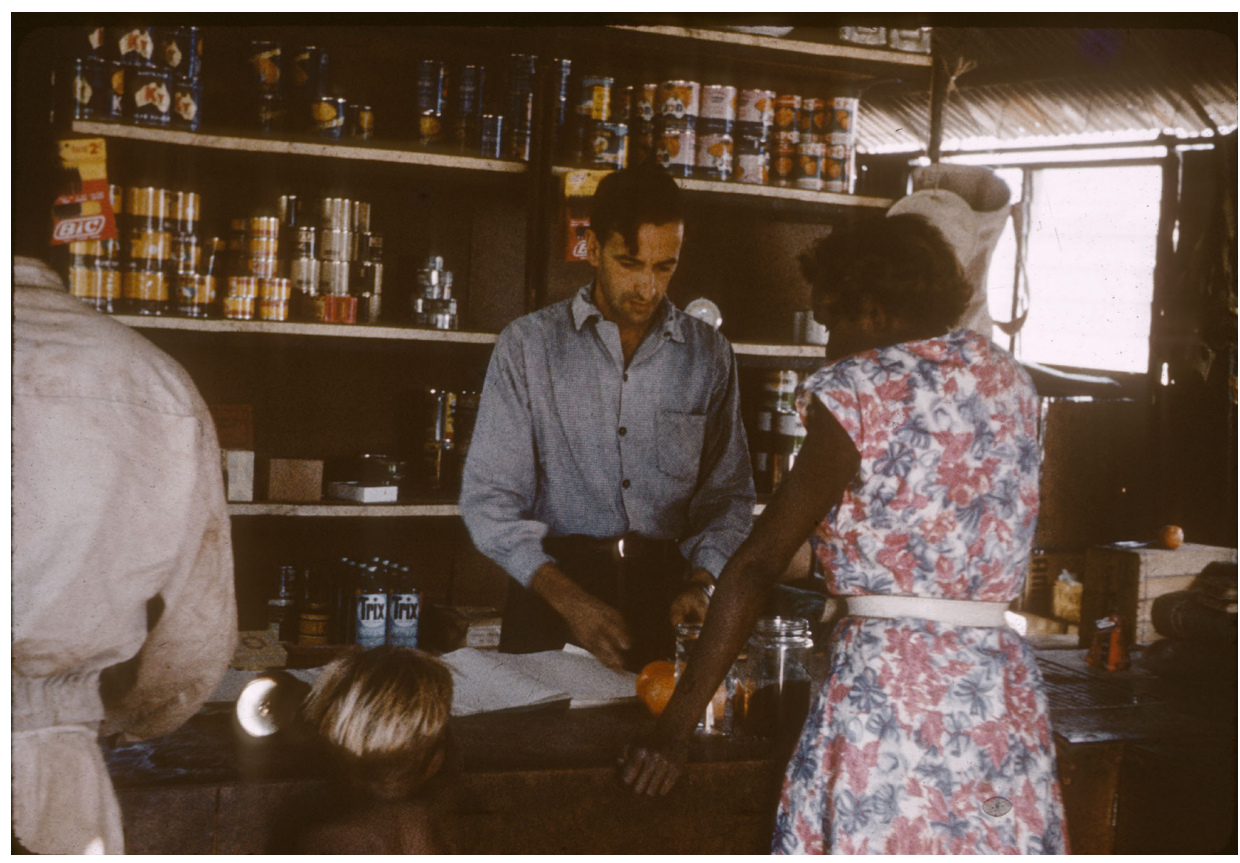

\section{Bill Edwards serving in the Ernabella trading store.}

Source: Photograph from Bill Edwards collection. Courtesy Ara Irititja Project Netley, South Australia.

In January 1958 I commenced a summer Institute of Linguistics course offered by the Wycliffe Bible Translators. This course, held at Belgrave Heights, east of Melbourne, provided training in phonetics, phonemics and grammar in order to assist missionaries to learn a previously unwritten language and devise an alphabet. It also provided some preparation for engagement in a crosscultural context.

\section{Ernabella Mission}

Ernabella Mission was established in 1937 in the lands of the Yankunytjatjara and Pitjantjanytjara peoples. These were two dialects of the Western Desert language group who refer to themselves as Anangu, a term meaning person or 
body. They occupy the Musgrave, Mann and Tomkinson ranges which stretch along the South Australia/Northern Territory border and sandhill country to the north and south of the ranges. Living as hunter-gatherers in small groups associated with the totemic centres related to the various species of the region such as the malu (kangaroo), kalaya (emu), ngintaka (perentie) and ili (native fig), they exploited the resources of the land as they moved from one water supply to another (Edwards 2004, pp. 37-47). Rituals were designed to ensure the continued supply of these resources.

The role of a Scottish-born surgeon, Dr Charles Duguid, was central to the establishment of Ernabella in 1937 (Kerin 2011). He and his wife Phyllis (née Lade) became strong advocates for the rights of Aboriginal people. In 1934, in his Adelaide practice, Duguid heard from a patient who had worked in Arnhem Land of abuses suffered by Aboriginal people in that region. He travelled to Alice Springs to investigate and was appalled by the living conditions of Aborigines and by stories of mistreatment (Duguid 1963, pp. 20-25). At Hermannsburg Mission, Pastor F. W. Albrecht suggested that Duguid examine the situation in the far north-west of South Australia. Duguid envisaged that:

An intelligent Christian mission, in my mind, is the only way, but those who attempt the task must have a knowledge of anthropology, must learn the language of the natives, and must have in them the spirit of Christ (Advertiser, 1934, p. 6).

Driving to Ernabella in 1935, Duguid observed discrimination on cattle stations and frontier settlements and heard reports of abuse of Aboriginal men's labour and the sexual abuse of women. He advocated the establishment of a mission to act as a buffer between the Aborigines and the encroaching white settlers and in 1936 persuaded the General Assembly of the Presbyterian Church to purchase the Ernabella lease. Ernabella Mission was thus administered by the Presbyterian Board of Missions from 1937 until 1973, when control was transferred to the Ernabella Community Council Inc.

Sheep work was central to the economy and the employment of Anangu residents who worked as shepherds, shearers, fencing contractors, well-sinkers and boring contractors. Women adapted a traditional method of spinning fibres to make hooked floor rugs, woven scarves and knee rugs from wool. Thus a craft industry was established in 1948. A school based on a vernacular education policy was opened in 1940. From 1945, a clinic was staffed by a nursing sister. Anangu were employed as aides in the school and clinic. Women baked bread and cooked meals for workers and school children. Men worked in the garden to provide vegetables for the kitchen, butchered sheep to supply meat and were employed in brick-making, maintenance and building work.

Following shearing, the people left on an annual 'walkabout' holiday, travelling west and south-west on camels, donkeys and on foot to visit traditional totemic 
areas. A similar holiday was taken after Christmas. These breaks enabled Anangu to maintain contact with traditional sites and the related knowledge and ceremony.

Although Ernabella was established as a Christian mission, little pressure was exerted for immediate results in the form of religious conversion. It was 15 years before the first baptisms were celebrated. Solid foundations were laid through learning the language, the example of staff, translation of the Gospel of Mark, and conducting regular services. As interest in the Christian story increased, a catechism was prepared in Pitjantjatjara. Early reports emphasised the role of singing in worship and the development of the choir. Several hymns were translated.

A report in December 1952 described the establishment of the Church at Ernabella, recalling that tribal sanctions had not been interfered with and that contact with the mission and engagement in the activities had been voluntary. A cement-block church building was erected in 1952. Local men were employed making and laying the blocks. On Sunday, 9 November, 1952, 400 people gathered for the dedication of the new church and in the afternoon 20 young people were baptised (Ernabella Newsletter 1952, pp. 5-6). Church members soon participated in church services by leading in prayer, reading Bible passages and preaching.

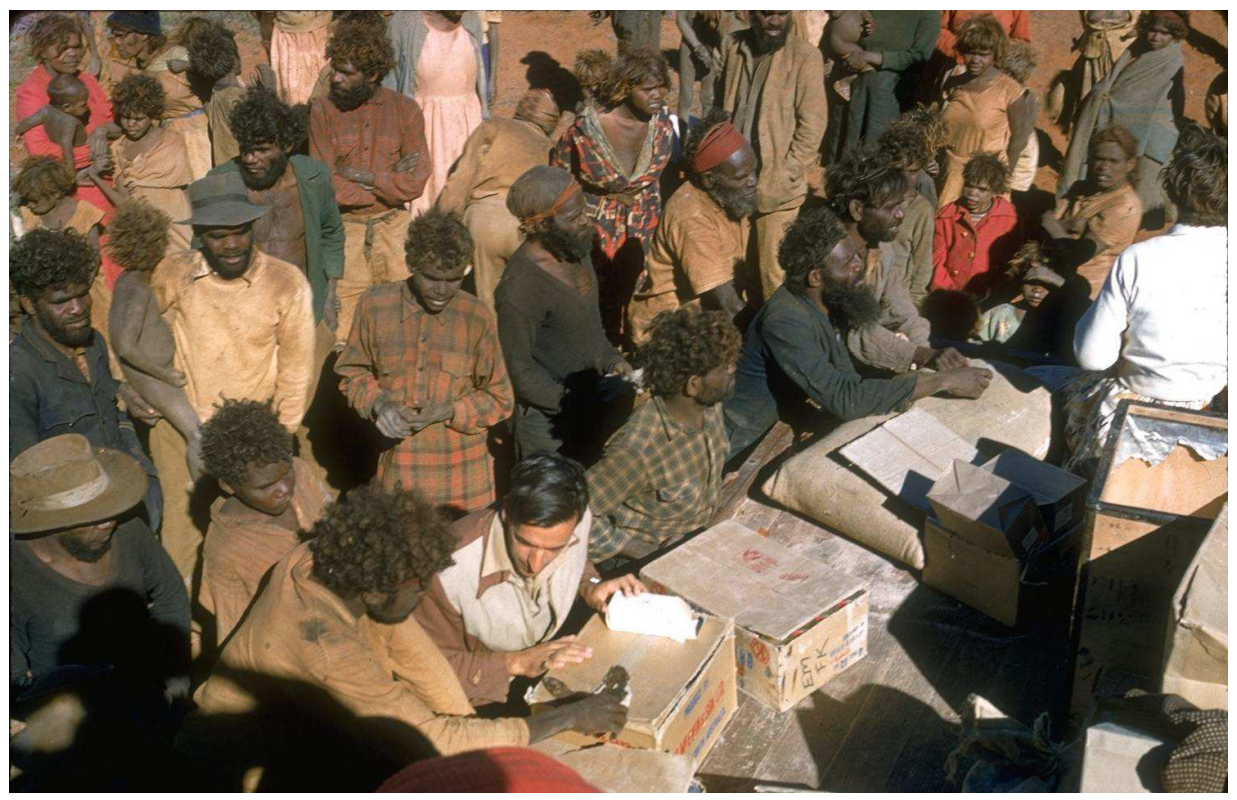

\section{Bill Edwards trading food with Anangu people in return for dingo scalps, Yulpartji, 1958.}

Source: Photograph from Bill Edwards collection. Courtesy Ara Irititja Project Netley, South Australia. 
As superintendent of Ernabella from 1958 to 1972, my tasks were varied as I pastored the church, managed the office and store, maintained financial records, coordinated the various departments of the mission, and supervised the local people in the garden, butchery and general maintenance. In 1961, Fregon cattle outstation was established 60 kilometres south-west of Ernabella to provide a home and employment for people who belonged to the sandhill country. The South Australian Government opened Amata settlement to the west of Ernabella in 1961, and Indulkana settlement, approximately 190 kilometres south-east of Ernabella, in 1968. I visited these stations monthly to conduct church services. Andy Tjilari resided at Fregon to preach and teach the catechism. In line with the mission's policy of respecting traditional culture and language, I visited traditional sites with Anangu people to learn some of the stories and observe ceremonies associated with the Tjukurpa or Dreaming heritage of the Anangu.

On a visit to a remote area in 1966, while walking across a sandhill I observed the footprints of dingoes and euros (hill kangaroos). Andy Tjilari joined me and pointed out from the tracks that a dingo had followed a euro, tackled it and dragged it towards a nearby rocky hill to feed its young. While I had seen some tracks, Andy, because of his long training in the bush, had observed a story. I thus gained a deeper understanding of the meaning of the words of Jeremiah, later cited by Jesus: 'Do you have eyes but fail to see, and ears but fail to hear?' (Jeremiah 5.21; Mark 8.18). For Anangu, the ground is a book from which they read the signs of what has taken place. My earlier education was based on learning from written records. Andy and other Anangu were teaching me to read the stories embedded in the landscape. As I gained increasing knowledge of fundamental concepts in Anangu thought and expression, I was able to apply this to my analysis of history and issues.

I completed a Bachelor of Education by external studies during my early years at Ernabella. Living in an isolated community, it would have been easy to lose touch with academic life. This study helped me to maintain contact. My first published paper was based on an assignment. I continued to reflect on my work, built up my own library and wrote papers on Aboriginal issues, often with an historical focus (for example, Edwards 1961, 1966, 1967, 1969). I had the advantage when writing about Aboriginal issues and history that I wrote from a grassroots position and from direct involvement. Day-to-day discussions with the mission's teacher, sheep overseer, church leaders and other colleagues were reflected in my writing of papers on education, employment and the relationship between culture and gospel.

While reflection and writing provided some relief from the pressures of the daily work, another fulfilling outlet was the role of training the Ernabella Choir. In line with the Anangu tradition of being participants rather than spectators, there was no separate choir in normal services as all people sang and learned 
parts. However, a choir sang for special Christmas and Easter pageants (in which real donkeys and camels featured) and when visiting other centres such as Alice Springs. Having worked with the choir for a few years, and remembering my first meeting with them in Adelaide in 1954, I arranged a tour to Adelaide, Melbourne and several provincial centres in Victoria and South Australia in 1966. This choir was comprised of 12 women and $12 \mathrm{men}$. The program included western hymns and folk songs, and performances of Anangu songs and dances. The response was overwhelming. Having envisaged singing in church halls to audiences of approximately 200 , local committees in provincial centres organised concerts in town halls with 700-900 attending. When a cancellation left a free night in the Melbourne Town Hall during the Moomba Festival, the choir was invited to perform before an enthusiastic audience of approximately 2,000. A broad smile beamed from the centre of the front row. It was Doug Nicholls, who I had heard speak at the university a decade earlier. In Adelaide, the choir was invited to attend a practice of the London Symphony Orchestra. Having finished their practice, the Orchestra played a Dvořák Slavonic Dance especially for the choir. In response, the choir sang the Pitjantjatjara version of 'The Lord is my Shepherd'.

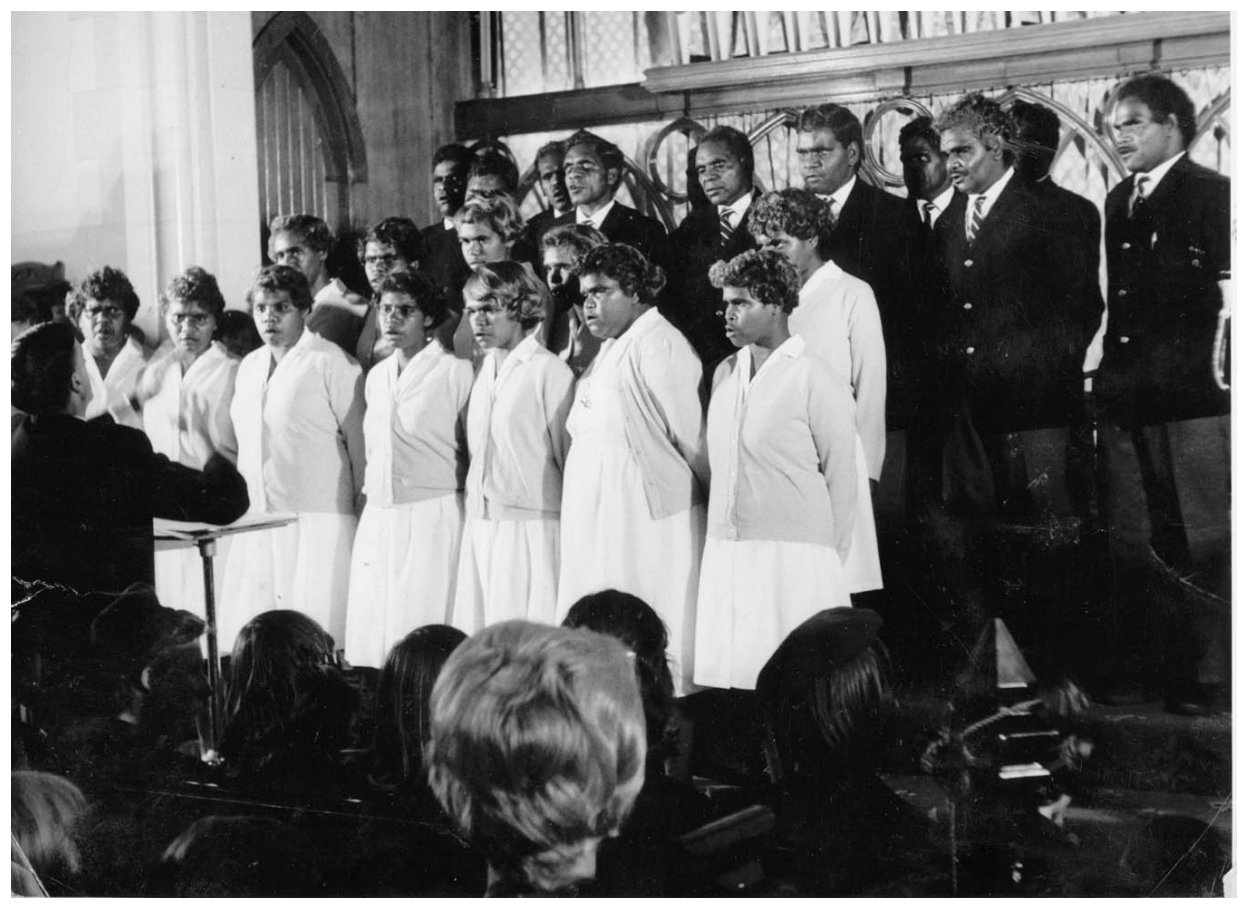

\section{Bill Edwards conducting the Ernabella Mission Choir, Scots Church, Adelaide March 1966.}

Source: Photograph from Bill Edwards collection. Courtesy Ara Irititja Project Netley, South Australia. 
Another enriching aspect of work at Ernabella was learning and speaking the Pitjantjatjara language. As well as communicating with Anangu in daily tasks and preaching in the language, I recorded and translated stories of their contact experiences with intruding white explorers and settlers, including reactions to first sightings of camels, horses and motor vehicles. Andy Tjilari's stories were evocative of the changing world he had experienced (Tjilari 2006). This added another perspective to my involvement in historical research, enabling me to bring Aboriginal experiences to the centre of historical analysis.

From the late 1960s, external and internal pressures forced changes in Aboriginal affairs as the policy of assimilation gave way to self-management and self-determination. In 1972, I moved to Mowanjum Mission in Western Australia to oversee the incorporation of the Aboriginal community and transfer of administration from mission to community. This became the prototype for this initiative. The same process took place at Ernabella and Fregon in 1973. I returned to the Anangu region to live at Fregon in 1973 as parish minister. In 1974, I studied theology at the Pacific Theological College and sociology at the University of the South Pacific in Fiji. Interacting with people from Pacific Island nations and learning of the structures and values of their societies enabled me to bring fresh insights to understanding Anangu society when I returned to the region in 1976. For example, reading Marshall Sahlins on social stratification in Pacific societies with his analysis of ascribed and achieved status in Polynesian societies and the role of Bigmen in Melanesia made me more aware of the problems confronting people from the egalitarian Anangu society as they encountered challenges in establishing new political structures (Edwards 1998, pp. 161-181). In 1975, I studied anthropology at the University of Adelaide and lectured in Aboriginal Studies at the Torrens College of Advanced Education.

\section{Return to the Anangu Lands}

In 1976, I returned to Anangu country to reside at Amata to minister in a parish that now stretched for 600 kilometres from east to west. Changes in government policies relating to Aboriginal people encouraged some Anangu to establish outstation or homeland communities in traditional totemic areas. Amata was near the centre of the total area. I was able therefore to intimately observe the development of the homeland movement in the region, a topic I have subsequently written of when changing government policies placed homelands under threat (Edwards 1993, 2013).

While I was occupied with conducting services, teaching, translating and training church elders, including my close friend Andy Tjilari, I increased my knowledge of Anangu Dreaming stories as I camped with people on the land. 
These experiences gave me new insights into the meaning of some Bible stories in a cross-cultural perspective, for the people of Israel had also at times gone 'walkabout' in deserts. Biblical references to God and the Holy Spirit as rock, fire and wind were meaningful for Anangu, who lived in close proximity to these elements. Soon after my arrival at Ernabella, when I was wearing sandals, a young woman exclaimed to her friends, 'Nyawa! Tjina wiru', 'Look at his beautiful feet'. Normally protected by shoes and socks, my feet contrasted markedly with their feet, which suffered injuries as they walked barefoot across rocks, hot sand, ashes and thorns. For the first time, I understood the mundane nature of the imagery expressed by Isaiah: 'How beautiful on the mountains are the feet of those who bring good news' (Isaiah, 52: 7). The feet of the messengers who brought Israelite captives news of their release were enclosed in sandals, whereas the feet of the Israelites had suffered as they walked across the hot desert sands. Singularities in the feet of Anangu contributed to their acclaimed ability as police trackers, as they could identify offenders by their footprints. For example, one person might be known to have bad cracking in the left heel while another had a bunion on the big toe of the right foot.

South Australian Premier Don Dunstan, who instituted sweeping changes in Aboriginal affairs at this time, had a long engagement with Aboriginal people and organisations. For example, he had Doug Nicholls appointed Governor of South Australia in 1976, the year of our move to Amata. Unfortunately, illhealth forced Nicholls to resign from the position before he had opportunity to visit Anangu communities.

Representatives from Anangu communities met at Amata in July 1976 to form the Pitjantjatjara Council as a forum for discussing issues and making representations to governments. At bi-monthly meetings they pressed for recognition of their right to ownership of the land. At the first meeting, I was invited to act as secretary and interpreter. Although I handed over the role of secretary to an Anangu person, I continued to record minutes of meetings in English and Pitjantjatjara and to interpret for four years. This latter task was crucial, as Anangu expressed their demands to Premier Dunstan and other politicians, public servants, lawyers and anthropologists whose cultural understandings were vastly different to those of the Anangu people. Negotiations between the South Australian Government and the Pitjantjatjara Council culminated in the enacting of legislation in March 1981 which granted inalienable freehold title to 102,360 square kilometres of land to Anangu Pitjantjatjara Inc. 


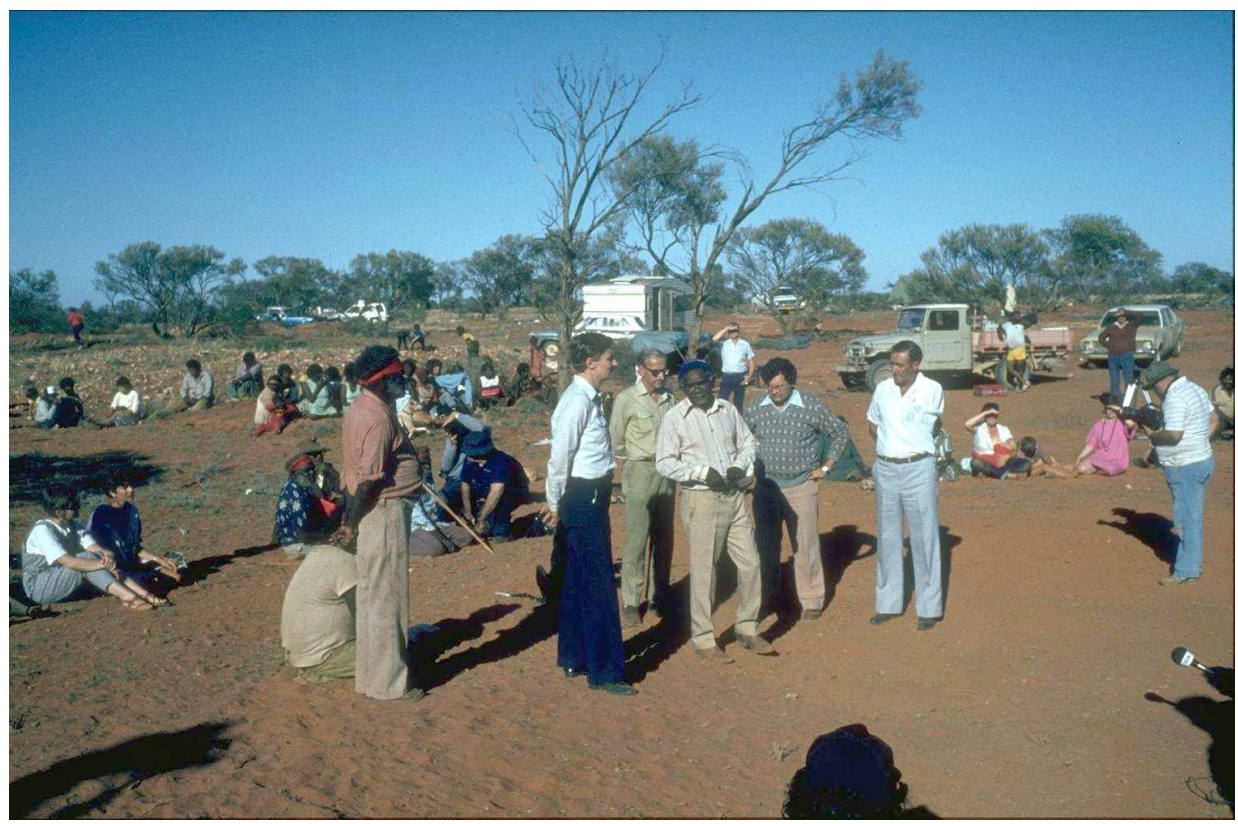

Bill Edwards interpreting with the Premier of South Australia, John Bannon, at the handover of title for the Maralinga lands to Maralinga Tjarutja Inc, December 1984.

Source: Photograph from Bill Edwards collection. Courtesy Ara Irititja Project Netley, South Australia.

Over this period, I wrote papers on various topics related to my involvement in these landmark political and social changes in Aboriginal affairs (for example, Edwards 1973, 1983). I was fortunate to have a close association with Anangu people who held strongly to traditional knowledge, values and practices while adjusting to the impact of European culture, and to be involved in the processes of change. I was part of the history and, as I reflected on what was happening about me, I was increasingly recording details in my diary, correspondence and minutes. After two decades of residence in the Anangu lands, my wife Valerie and I moved to Adelaide. Our sons commenced their schooling in Anangu schools, but needed to be nearer other schools for their secondary education. I had confidence too, that the 25 Anangu men and women ordained as Church Elders could fulfill the ministry in the churches across the Anangu lands. One of them, Peter Nyaningu, was undertaking studies for ordination as a minister of the Uniting Church of Australia. Having studied and lectured in Adelaide in 1975, we returned there in 1981 so that I could continue studies in anthropology and lecture in Aboriginal studies at what was to become the South Australian College of Advanced Education, which was incorporated into the newly established University of South Australia in 1991. 


\section{Teaching and Researching in Adelaide}

My main areas of teaching were traditional Aboriginal culture and Pitjantjatjara language. I also lectured on land rights, traditional Aboriginal education and health. As there was a growing awareness of the need for students enrolled in other courses to learn about Aboriginal culture, I pioneered the teaching of Aboriginal culture subjects in nursing, parks and wildlife, education and other courses. I also conducted cultural awareness workshops for police trainees, librarians, teachers and hospital staff. While I structured these workshops and taught about the Anangu concept of the Dreaming and the basic structures of their kinship system, I invited Aboriginal people to share their personal knowledge and experiences. Andy Tjilari's younger brother, Gordon Ingakatji, who had assisted me in the store and office at Ernabella and been my principal language teacher, came to Adelaide periodically to assist in teaching Pitjantjatjara. Mona Tur, a Yankunytjatjara woman, who came to Adelaide as a teenager and later married there, also worked with me in language teaching.

At that time, there were few Indigenous academics in Australia. Most Aboriginal Studies teaching was done by non-Indigenous people. Some Aboriginal students in these courses later became leaders in Aboriginal education and Indigenous studies around Australia. Most of the Aboriginal students came from urban or rural backgrounds and had limited experience of 'traditional' cultural life. Most respected that I had some experience of this and were willing to learn from me. On the other hand, I learned much from them about their cultural life as people of mixed descent whose families had often suffered discrimination. It was another case of ngapartji ngapartji, reciprocal engagement. Some of these Aboriginal students commented in their assignments that they had lost their culture. I reminded them that as human beings they had been enculturated and that, although their particular culture differed to that of their Aboriginal forebears, it was a culture to be equally valued. I encouraged them to build on the positive values of that culture and to recall things told to them by their parents or grandparents, to consider whether these stories reflected elements of traditional culture.

While my residence in the Anangu lands for two decades provided a wealth of knowledge and experience to share with students, I continued to have active involvement and advocacy in Aboriginal issues. Before leaving the Anangu lands, I interpreted in negotiations which led eventually to the granting of land rights over Uluru (Ayers Rock) National Park in 1984. I interpreted for the Maralinga Tjarutja people, whose land lies south of the Pitjantjatjara lands, in their land rights claim. I also interpreted for the Maralinga people during the Royal Commission into British Nuclear Testing in Australia. I was called upon to interpret for Anangu people in the legal and health sectors, a task that 
took me into courts, prisons, forensic mental health institutions, hospitals and other institutions. I visited the Anangu lands annually to conduct workshops, interpret, attend funerals and celebrations and to meet old friends. I continued my association with the Ernabella Choir, conducting them on a visit to Sydney and other centres in New South Wales in 1984 and at a performance in the Adelaide Town Hall during the 2004 Adelaide Festival of Arts, half a century after my first encounter with them in Adelaide.

As a lecturer in Aboriginal studies, I was confronted by critical comments about the role of missions in Aboriginal experience in Australia. While I was well aware of the shortcomings of some mission policies and practices, I was concerned at the stereotyping and lack of detailed research which often underlay these criticisms. Earlier romanticised depictions of missions had given way to distorted presentations. Eric Sharpe expressed this change as follows:

From confident assurance before 1914, the record has proceeded by way of paradox and ambiguity in a general direction of a gloomy but superficial catalogue of failure. In the first phase, the missionary seemingly could do no wrong; in the last, one sometimes wonders whether the missionary can ever be given credit for doing anything right (Sharpe 1989, p. 79).

An example of this negative view is found in the entry on 'Missions' by historian Ian Clark in The Encyclopaedia of Aboriginal Australia, where he writes that 'the word means a place where many of our people were "imprisoned"'(Clark 1994, vol. 2. p. 706). The entry continues in this vein with little reference to specific missions and stereotypes are reinforced. No account is taken of the very positive comments expressed by many Aboriginal people about their experiences of mission life (Edwards 2007, p. 23, fn 63), albeit in a system that, like all non-Indigenous institutions, was imbricated in colonialism. Dennis Ingram, May O'Brien and Denzil Humphries, for example, have written positively about the care, example and training provided by missionaries and of the opportunities this opened up for them in later life (Taylor 1998, pp. 240, 332, 333). Another aspect often overlooked is the involvement of Aboriginal people themselves in this enterprise, for example, David Unaipon, Nathaniel Pepper, Doug Nicholls, Blind Moses and other Arrente evangelists in Central Australia, Reverend Lazarus Lamilami, James and Angelina Noble, and Pastor Ben Mason. While missionaries are sometimes validly accused of removing people from their lands and destroying their culture, in many instances it was missions that enabled people to remain in their country and maintain their language and cultural practices. Marcia Langton noted that 'if it had not been for missions, there would be no Aboriginal people alive in Victoria today' (Perkins 2008) and Noel Pearson similarly stated that 'missions did not destroy the culture that remains, as some often allege' (Pearson 1998, p. 147). 
My venture into post-graduate research in mission historiography was partly motivated by a concern to counter such inaccuracies as identified by Langton and Pearson. I was encouraged by the publication of several books which provided a more balanced approach to the study of mission history (for example, McDonald 2001; Choo 2001; Loos 2007; Kenny 2007). Writing of the massacre of Aborigines in Western Australia, Neville Green provided an example of a missionary, Ernest Gribble, who sought justice on behalf of Indigenous people despite facing hostile opposition (Green 1995).

In 1991, a seven-week sabbatical at the Centre for the Study of Christianity in the Non-Western World at the University of Edinburgh broadened my understanding of mission history. I came across references to Moravian missions. Missionaries from the Moravian church in Saxony pioneered several Protestant mission fields from the early eighteenth century and from the 1890s provided staff for Presbyterian missions in north Queensland. As I wrote papers on Presbyterian missions in which I had been involved, I was referring to Moravians. In 1994, I spent a week at a Moravian College and Archive in Bethlehem, Pennsylvania. The archivist produced a box of letters written from 1866 to 1874 by Mary Hartmann, wife of a Moravian missionary, from Ebenezer in Victoria, to her parents in England. To my knowledge, no writer on Aboriginal history had accessed these letters previously. They gave vivid descriptions of the complex daily interaction of missionaries and Aboriginal people in their homes and gardens and on picnics, details often overlooked in the stereotyped presentations of Aboriginal missions.

Two 1870 letters record the care given by the Hartmanns in their home to a dying man named Dick-a-Dick. Two years earlier, Dick-a-Dick played for the first Australian cricket team to tour England, a team comprised of Aboriginal players. In 1864, Dick-a-Dick was one of three Aboriginal trackers who found three young children, Jane, Isaac and Frank Duff, who wandered from a station near Apsley in western Victoria and were lost in the bush for nine days. As a child, I read an account of this in Victoria's Grade IV Reader. My mother, as a child in Horsham, visited the home of Jane Turnbull (formerly Jane Duff), to hear her recount this experience (Edwards 1999b, pp. 59-61).

A Professor of History at Flinders University in Adelaide commented favourably on some of my publications and this encouraged me to undertake doctoral research on the history of Moravian missions in Australia under his supervision. I intended, in retirement, to write on the work in which I had been involved. However, I chose the Moravian missions for my thesis in order to enable me to engage with Aboriginal mission historiography more 'objectively'. I intended returning to writing about Ernabella after honing my skills in mission history by researching the Moravians. 
At one stage of my writing, when I was feeling uncertain, a colleague who had gained her doctorate in anthropology offered to read drafts of my chapters. She suggested I was too reticent about intruding my own experience when writing about the Moravians, of deploying this as a methodology. There were many correspondences between the work at Ebenezer and Ernabella and I had written a seminar paper entitled 'A Moravian Mission in Australia, Ebenezer Through Ernabella Eyes'. I began to realise that my experiences gave me unique insights into situations in which Moravian missionaries had been involved a century earlier. This enhanced my practice as a historian. My colleague's suggestion contributed to the successful completion of my thesis.

\section{Conclusion}

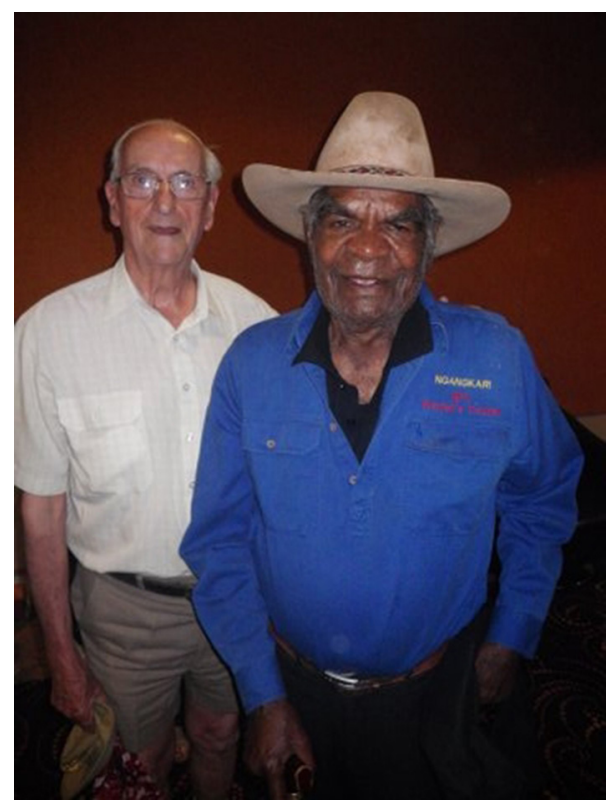

\section{Bill Edwards and Andy Tjilari, 2012, a lifelong friendship.}

Source: Photograph from Bill Edwards collection. Courtesy Ara Irititja Project Netley, South Australia.

I am now proceeding with research, reflection and writing on Ernabella. The year in which I write this is the $75^{\text {th }}$ anniversary of Ernabella's establishment. To celebrate this, I gave a lecture to the Uniting Church Historical Society in Adelaide in May 2012 entitled 'Mission in the Musgrave: Ernabella Mission 1937-73, a place of relationships' (Edwards 2012). I was concerned that much of the writing about Christian missions in Australia was clouded by stereotypes which overlooked the daily interaction of mission staff and Aboriginal residents 
and their influence on each other in a co-created world. Having researched the relationships between women missionaries and Indigenous women, Patricia Grimshaw contends that theorists dismissive about the entire mission enterprise conflate 'the outcomes of missionary endeavours with the destructiveness of other colonial intruders' (Grimshaw 2011, p. 10). Grimshaw concluded that the outcomes of joint endeavours in the fields of education and health were 'negated largely because of the specific nature of settler colonialism in Australia and its sharply racialised boundaries' (Grimshaw 2011, p. 24).

As I read contemporary reports of social problems and dysfunction in remote Indigenous communities and am confronted by these issues as I interpret in courts, prisons and hospitals, the words of the anthropologists, John and Jean Comaroff, writing of post-colonial southern Africa, resonate with my experience. They refer to 'the inherent contradictions of colonialism' in Africa and the problems encountered by missions in their 'campaign to refashion the African personhood' as 'a study in ambiguity, contradiction, and the sheer perversity of the unintended in history' (Comaroff J L \& J Comaroff 1997, p. 368).

Discovering the letters written by Polly Hartmann, from Ebenezer Mission in Victoria, to her parents in England, with their insights into the relationships between missionaries and Aborigines, further prompted my interest in this aspect of mission history and lent insight into my role as an historian shaped by the worlds I was writing about. After my parents died, I discovered not only the etched boomerang referred to earlier, but that they had kept my weekly letters to them. Thus, as I return to recording the history of Ernabella, I have documents that provide details of dates, events and people. My writing of this history cannot be objective, as I have been a participant in these events as well as in the negotiations that culminated in the recognition of land rights for the Pitjantjatjara/Yankunytjatjara, Uluru and Maralinga lands. My writing of Anangu history is inextricably bound to my personal story, a project that is both autobiographical and historical in which my development as an historian has been influenced directly by the history in which I was immersed, and thus an example of ego-histoire. 


\section{References}

Advertiser 1934, 'Treatment of Aborigines: Criticism by Dr. Duguid', The Advertiser, Adelaide, 28 December, 1934.

Attwood, B 2003, Rights for Aborigines, Allen \& Unwin, Crows Nest.

Batty, P (ed.), 2006, Colliding Worlds: First contact in the Western Desert, 1932-1984, Museum Victoria, Melbourne.

Choo, C 2001, Mission Girls: Aboriginal women on Catholic Missions in the Kimberley, Western Australia, University of Western Australia Press, Crawley.

Clark, I D 1994, 'Missions', in D Horton (ed.), The Encyclopaedia of Aboriginal Australia, 2 vols, Aboriginal Studies Press, Canberra.

Clark, I D 1990, Aboriginal Languages and Clans: An historical atlas of western and central Victoria, 1800-1900, Monash University, Melbourne.

Clark, M 1972, Pastor Doug: The Story of Sir Douglas Nicholls, Aboriginal Leader, Landsdowne, Melbourne.

Comaroff J L \& J Comaroff 1997, Of Revelation and Revolution, vol. 2: The Dialectics of Modernity on a South African Frontier, The University of Chicago Press, Chicago.

Duguid, C 1963, No Dying Race, Rigby Ltd, Adelaide.

Edwards, B 1999a, Moravian Aboriginal Missions in Australia, 1850-1919, Uniting Church Historical Society (S.A.), Adelaide.

Edwards, B 1999b, 'The Fate of an Aboriginal Cricketer: When and where did Dick-a-Dick die', Australian Aboriginal Studies, no. 2, 1999.

Edwards, B \& B Clarke 1988, 'From Missions to Aboriginal Churches: The Uniting Church in Australia and Aboriginal Missions', in T Swain and D B Rose (eds), Aboriginal Australians and Christian Missions, Australian Association for Religious Studies, Bedford Park.

Edwards, W H 2013, 'From Coombes to Coombs: Reflections on the Pitjantjatjara outstation movement', paper presented at workshop on the Aboriginal Outstation Movement, The Australian National University.

Edwards, W H 2012, Mission in the Musgrave: Ernabella Mission 1937-73, a place of relationships, Uniting Church Historical Society (S.A.), Adelaide. 
Ngapartji Ngapartji, In Turn, In Turn: Ego-histoire, Europe and Indigenous Australia

Edwards, W H 2007, 'Moravian Aboriginal Missions in Australia', unpublished $\mathrm{PhD}$ thesis, Flinders University, Adelaide.

Edwards. W H 2005, 'Tjukurpa Palya: The Good Word: Pitjantjatjara responses to Christianity', in Peggy Brock (ed.), Indigenous Peoples and Religious Change, Brill, Leiden.

Edwards, W H 2004, An Introduction to Aboriginal Societies, second edition, Thomson Social Science Press, South Melbourne.

Edwards, W H 1998, 'Leadership in Aboriginal Societies', in W H Edwards (ed.), Traditional Aboriginal Society, Macmillan Education Australia, Melbourne.

Edwards, W H 1993, 'Patterns of Aboriginal Residence in the North-West of South Australia', Journal of the Anthropological Society of South Australia, vol. 30, no. 1-2.

Edwards, W H 1983, 'Pitjantjatjara Land Rights', in N Peterson and M Langton (eds), Aborigines, Land and Land Rights, Australian Institute for Aboriginal Studies, Canberra.

Edwards, W H 1978, 'The Gospel and Aboriginal Culture'. Interchange, no. 24, pp. 195-204.

Edwards, W H 1973, 'The Changing Climate of Aboriginal Development', Interchange, no. 14, pp. 70-80.

Edwards, W H 1969, 'Experience in the Use of the Vernacular as an Introductory Medium of Instruction', in S S Dunn and C M Tatz (eds), Aborigines and Education, Sun Books, Melbourne.

Edwards, W H 1967, 'Communicating the Gospel to Australian Aborigines', The Bulletin, Christian Institute for Ethnic Studies in Asia, vol. 1, no. 1.

Edwards, W H 1966, 'Report on Ernabella Labour Export Project, 1965-66', in I G Sharp and C M Tatz (eds), Aborigines in the Economy, Jacaranda Press, Melbourne.

Edwards, W H 1961, 'Aboriginal Education: Aims and principles', Journal of Christian Education, vol. 4, no. 1.

Elkin, A P 1956, The Australian Aborigines: How to understand them, second edition, Angus \& Robertson, Sydney.

Ernabella Newsletter, December 1952, Australian Presbyterian Board of Missions, Sydney. 
Giles, E 1889, Australia Twice Traversed, 2 vols, Sampson Low, Marston, Searle \& Rivington.

Green, N 1995, The Forrest River Massacres, Fremantle Arts Centre Press, South Fremantle.

Grimshaw, P 2011, 'Rethinking Approaches to Women and Missions: The case of colonial Australia', History Australia, vol. 8, no. 3.

Hilliard, W 1968, The People in Between: The Pitjantjatjara People of Ernabella, Hodder and Stoughton, London.

Kenny, R 2007, The Lamb Enters the Dreaming: Nathanael Pepper and the ruptured world, Scribe Publications, Carlton North.

Kerin, R 2011, Doctor Do-Good: Charles Duguid and Aboriginal advancement, 1930s-1970s, Australian Scholarly Publishing, North Melbourne.

Loos, N 2007, White Christ Black Cross: The emergence of a black church, Aboriginal Studies Press, Canberra.

McDonald, H 2001, Blood, Bones and Spirit: Aboriginal Christianity, Melbourne University Press, Carlton South.

Neill, S 1964, A History of Christian Missions, Penguin Books, Harmondsworth.

Pearson, N 1998, 'Ngamu-Ngaadyari, Muuri-Bunggaga and Midha Mini in Guugu Yimidhirr History', in Jan Kociumbas (ed.), Maps, Dreams, History: Race and representation in Australia, University of Sydney, Sydney.

Perkins R 2008, 'Episode 3: Freedom for our lifetime', The First Australians, Blackfella Films.

Sharpe, E J 1989, 'Reflections on Missionary Historiography', International Bulletin of Missionary Research, vol. 13, no. 2.

Stanner, W E H 1969, 'After the Dreaming', The Boyer Lectures 1968, ABC, Sydney.

Taylor, P 1988, After 200 Years: Photographic Essays of Aboriginal and Islander Australia today, Aboriginal Studies Press, Canberra.

Tjilari, A 2006, Learning as a Pitjantjatjara Child/Ngayulu Iriti Tjitji Nintiringkunytja, (originally recorded and translated by Bill Edwards), Department of Education and Children's Services, Adelaide. 
This text taken from Ngapartji Ngpartji: In turn in turn:

Ego-histoire, Europe and Indigenous Australia

Edited by Vanessa Castejon, Anna Cole, Oliver Haag and Karen Hughes,

published 2014 by ANU Press, The Australian National University, Canberra, Australia. 